\title{
Porto das Barcas e galpões portuários em Parnaíba [PI]: memória, patrimônio e identidade
}

DOSSIER DE PESQUISA : PATRIMÔNIO INDUSTRIAL No NoRTE E NORDESTE Do BRASIL

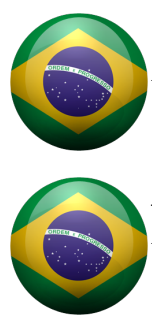

Ísis Meireles Rodrigues Sampaio

Arquiteta e Urbanista, Doutoranda em Arquitetura e Urbanismo pela Escola de Arquitetura - Universidade Federal de Minas Gerais. Belo Horizonte [MG] Brasil. <isismrs@ufmg.com.br>

\section{Aracelly Moreira Magalhães}

Arquiteta e Urbanista, Mestre em Construção Civil pela FUMEC, Centro Universitário Uninovafapi. Teresina [PI] Brasil. <ammagalhaes@uninovafapi.edu.br>

\section{Resumo}

0 presente trabalho aborda a dimensão material e imaterial do patrimônio industrial da cidade de Parnaíba, localizada na região litorânea do Estado do Piauí, nordeste do Brasil. Possui como objeto de estudo o espaço delimitado pelo Conjunto do Porto das Barcas e galpões Portuários, parte integrante do Conjunto Histórico e paisagístico de Parnaíba, tombando pelo Instituto do Patrimônio Histórico e Artístico Nacional, IPHAN, no ano de 2008. 0 objetivo geral é compreender a relação entre espaço, democracia, cultura, memória e identidade na produção e gestão do patrimônio histórico urbano. A metodologia utilizada baseia-se na pesquisa documental, pesquisa histórica e pesquisa arquitetônica. Busca-se refletir, de maneira pluridisciplinar, sobre patrimônio, apropriação social e democracia a partir de uma perspectiva mais ampla, simultaneamente municipal e histórica, social e política. A dissolução do patrimônio urbano impacta diretamente nos valores comuns de uma sociedade 0 presente trabalho justifica-se pelo pela importância que o ambiente construído possui para o desenvolvimento de determinada sociedade. Procura-se uma melhor compreensão propiciada pelo conhecimento histórico acerca do patrimônio e das relações de memória e identidade de determinado local, de maneira a auxiliar no planejamento urbano contemporâneo, no fortalecimento da cultura urbana e na salvaguarda do patrimônio histórico, uma vez que a eficácia da patrimonialização e revitalização está relacionada com a preservação e salvaguarda da história e do fortalecimento da identidade de um local a partir de uma apropriação social ativa e democrática.

\section{Palavras-chave}

Identidade. Memória. Parnaíba. Patrimônio.

\section{"Porto das Barcas" and harbor sheds in Parnaíba [state of Piaui, Brazi]: memory, heritage and identity}

\begin{abstract}
This paper deals with the material and immaterial dimension of the industrial patrimony of the city of Parnaíba, located in the coastal region of the State of Piauí, northeastern Brazil. It has as object of study the space delimited by the Porto das Barcas Complex and port warehouses, an integral part of the Historic and Landscape Set of Parnaíba, protected by the National Historical and Artistic Heritage Institute, IPHAN, in 2008. The general objective is to understand the relationship between space, democracy, culture, memory and identity in the production and management of urban historical heritage. The methodology used is based on documentary research, historical research and architectural research. It seeks to reflect, in an interdisciplinary way, on heritage, social appropriation and democracy from a broader perspective, simultaneously municipal and historical, social and political. The dissolution of the urban patrimony directly impacts on the common values of a society The present work is justified by the importance that the built environment has for the development of a certain society. A better understanding of the heritage and memory and identity relations of a given place is sought in order to assist in contemporary urban planning, the strengthening of urban culture and the safeguarding of historical heritage, since the effectiveness patrimonialization and revitalization is related to the preservation and safeguarding of history and the strengthening of the identity of a place from an active and democratic social appropriation.
\end{abstract}

\section{Keywords}

Identidy. Heritage. Memory. Parnaíba. 


\section{Introdução}

O presente trabalho, intitulado "Porto das Barcas e galpões portuários em Parnaíba, PI: Memória, patrimônio e identidade" trata da dimensão material e imaterial do patrimônio da cidade de Parnaíba, localizada na região litorânea do Estado do Piauí, nordeste do Brasil. Possui como objeto de estudo o espaço delimitado pelo Conjunto do Porto das Barcas e galpões Portuários, parte integrante do Conjunto Histórico e paisagístico de Parnaíba, tombando pelo Instituto do Patrimônio Histórico e Artístico Nacional (IPHAN), no ano de 2008.

A cidade de Parnaíba foi fundada por Domingos Dias da Silva, no ano de 1758 ao se estabelecer em uma fazenda, baseada na indústria do charque e apoiando-se na navegabilidade do rio Parnaíba (Mendes, 2007). Possuiu em sua formação intensa atividade econômica extrativa e exportadora, o que garantiu grande abertura sócio econômica e diversidade arquitetônica na formação de sua paisagem urbana histórica.

O conjunto escolhido, como mencionado, integra a Paisagem Urbana Histórica de uma cidade de potencial turístico e econômico para o Piauí e vizinhança. Entende-se por Paisagem Urbana Histórica a definição utilizada pela UNESCO no preambulo de "Recomendações sobre a paisagem histórica urbana" que a considera resultado da sobreposição de valores e atributos culturais e naturais de um local, estendendo o contexto urbano para além de seu centro histórico.

Para compreender as relações entre as representações sociais, o ambiente construído e o potencial democrático dos espaços públicos, em especial daqueles constituintes de Patrimônio Histórico, deve-se iniciar pela definição acerca do que é Arquitetura. Para Rappaport (1984) arquitetura pode ser definida como qualquer construção que muda deliberadamente o ambiente físico de acordo com algum esquema diretor. E, mais do que desenhos ou projetos, arquitetura é resultado de fenômenos sócios culturais e refletem as ideologias, modo de viver, habitar e organização social de determinada comunidade. Arquitetura pode também ser definida como um conjunto analisável de signos. E, a significação do objeto arquitetônico inclui as relações sociais nele praticadas, da produção do indivíduo e de sua relação com os demais. Para Coelho Netto (1993 p.46) é necessário "conhecer o significado preciso que uma ordenação espacial assume para determinado grupo social" e passar então a entender como o espaço "ganha ou perde significados, sentidos, significações" ocasionados a partir da prática do espaço, seja ela física ou imaginária.

Dessa forma, o desenvolvimento da pesquisa partiu de um questionamento central sobre qual a relação de memória, identidade e cultura de uma sociedade e a preservação do seu Patrimônio edificado. A partir dessa problemática inicial, outras questões se fizeram presentes para a compreensão do objeto de estudo, tais como: 0 que torna um patrimônio cultural democrático? Qual o potencial democrático do conjunto analisado? A pesquisa possui a hipótese que espaços de valor patrimonial têm potencial de apropriação democrática reforçado pelas relações de memória e identidade socialmente construídas acerca de determinado local.

O objetivo geral desse estudo é, portanto, analisar o potencial democrático do patrimônio urbano do Conjunto histórico Porto das Barcas e Galpões portuários em Parnaíba [PI]. Busca-se compreender a relação entre espaço, democracia, cultura, memória e identidade na produção e gestão do patrimônio histórico urbano.

A metodologia utilizada baseia-se na pesquisa documental, pesquisa histórica e pesquisa arquitetônica. 0 aporte teórico utilizado na revisão da literatura e na construção do trabalho baseia-se em autores essenciais para compreensão e caracterização das formas volumétricas e arquitetônicas dos edifícios de maneira geral, como Choay (2001). Sobre cidade e espaços públicos utiliza-se autores como Henri Lefebvre (2008). As referências empregadas para construção do sentido de memória foram Maurice Halbwachs (1990) e Pierre Nora (1993), além de autores como Chartier (2012) e Bauman (2012) na construção dos conceitos de cultura, entre outros. Busca-se refletir, de maneira pluridiciplinar, sobre patrimônio, apropriação social e democracia a partir de uma perspectiva mais ampla, simultaneamente municipal e histórica, social e política.

A dissolução do patrimônio urbano impacta diretamente nos valores comuns de uma sociedade 0 presente trabalho justifica-se pelo pela importância que o ambiente construído possui para 0 
desenvolvimento de determinada sociedade. Procura-se uma melhor compreensão propiciada pelo conhecimento histórico acerca do patrimônio e das relações de memória e identidade de determinado local, de maneira a auxiliar no planejamento urbano contemporâneo, no fortalecimento da cultura urbana e na salvaguarda do patrimônio histórico, uma vez que a eficácia da patrimonialização e revitalização está relacionada com a preservação e salvaguarda da história e do fortalecimento da identidade de um local a partir de uma apropriação social ativa e democrática. Espera-se que a compreensão das relações citadas anteriormente possibilite um melhor entendimento e direcionamento para as políticas atuais de salvaguarda, passível de aplicação não apenas no sitio analisado, mas em objetos de estudo semelhantes.

\section{Metodologia}

Apesar do recorte cronológico da pesquisa inserir-se na contemporaneidade também aborda fenômenos históricos, sendo, portanto, imprescindível neste trabalho a utilização da pesquisa histórica como método.

A pesquisa histórica, concordando com o pensamento de Benévolo (1984) possui natureza funcional sendo essencial para o entendimento de um objeto analisado: "O esclarecimento do processo que levou à situação atual constitui na verdade uma premissa indispensável para abordar essa situação de maneira realista" (Benevolo, 1984). Além disso, o Estudo de caso descritivo também será aplicado ao problema proposto, uma vez que se busca o entendimento de um evento contemporâneo existente na realidade que não exige controle de eventos comportamentais e cujas fronteiras entre fenômeno e contexto não são claramente evidentes. Dessa maneira, busca-se formular uma perspectiva mais holística ao se utilizar de evidencias múltiplas que vão além dos fornecidos pelo campo da pesquisa histórica.

No problema proposto, a delimitação temporal de estudo perpassa tanto a própria formação urbana da paisagem (a ser realizado de maneira concomitante com o método da pesquisa histórica) quanto a interpretação realizada coletivamente sobre ela nos dias atuais. Dessa forma, os procedimentos metodológicos escolhidos para a realização dessa pesquisa podem ser sintetizados nas seguintes etapas: Primeiramente realizou-se a pesquisa histórica e documental além da revisão e construção do aporte teórico sobre o objeto de estudo buscando o entendimento de cultura, patrimônio, espaço e democracia para em seguida relaciona-las num contexto específico através do estudo de caso do Conjunto Porto das Barcas e galpões portuários em Parnaíba [PI]. Também buscou-se auxílio na pesquisa arquitetônica, análise visual e em estudos morfológicos.

\section{Referencial teórico}

\subsection{Sociedade, cultura, espaço e democracia}

Inicialmente, faz-se necessário compreender o que se entende pelo termo cultura. A origem da palavra faz alusão ao processo de cultivar, criar. Em meados do séc. XVIII, cultura distinguia as realizações do homem em relação ao mundo natural. "'Cultura' significava aquilo que os homens podem fazer" (Bauman, 2012 p.12). Pode-se entende-la com um sentido de permanência, realizado através da transmissão (cultura como educação), forma pela qual se atinge a "humanização do homem", considerada também como "mecanismo imprescindível para sobrevivência dos grupos e espécies" (Sacristan \& Gómez, 1998 p.13). Para autores como Moura (2009 p.12), cultura significa "o horizonte que torna possível a materialização do gênio humano" ou ainda "suporte de uma vivência concreta".

Verifica-se, portanto, uma relação íntima entre cultura e contexto social. É entendida como o que se espera que alguém saiba ou faça para ser reconhecido entre seus semelhantes. Dessa forma o entendimento de cultura passou pelas definições de comportamento aprendido, legado social adquirido pelo homem e ainda, mecanismo para regulamentação normativa do comportamento. Assim, é possível compreender cultura como algo pertencente a um contexto que só é passível de compreensão dentro de um sistema simbólico (Geertz, 2014).

Cultura pode também ser definida como forma de expressão da ideia de pertencimento expressa no cotidiano. A vida cotidiana é realidade interpretada pelos homens e dotada de sentido de 
maneira subjetiva. 0 senso comum é aquilo que se partilha na vida cotidiana e o conhecimento é socialmente distribuído pelos indivíduos (Berger \& Luckmann, 2008). Para Heller (1992 p.21) "a vida cotidiana não esta 'fora' da história, mas ao 'centro' do acontecer histórico: é a verdadeira essência da substância social."

Geertz (2014) define cultura como interpretação, necessitando de estruturas de significação e códigos estabelecidos para seu entendimento. Possui natureza pública e social sendo indissociável das ações humanas, uma vez que "o comportamento humano é visto como ação simbólica "(Geertz, 2014 p.8). Dessa maneira, tem-se "o reconhecimento das práticas de apropriação cultural como formas diferenciadas de interpretação" (Chartier, 1990 p.28). Portanto, a cultura é assimilada como transmissão histórica de significados apropriados em símbolos, heranças expressas de maneira simbólica por meio da qual os indivíduos se comunicam e se desenvolvem, estando cultura e sociedade estreitamente articuladas.

Esse universo simbólico relaciona a contemporaneidade e seu passado numa totalidade dotada de sentido, organizando o que se entende por história. E, em relação aos acontecimentos passados, estabelece uma memória a ser compartilhada (Berger \& Luckmann, 2008). 0 pensamento de um indivíduo é o que o mesmo tem em comum com seus contemporâneos. Logo, a História cultural se relaciona com a maneira de conceber as relações entre os grupos sociais e os níveis culturais (Chartier, 1990 p. 45). Por meio dela pode-se explicar as diferenças entre as organizações sociais, comunidades, sejam essas diferenças de nacionalidade, etnias, cronológicas ou socialmente discriminadas (Bauman, 2012).

Observa-se uma aproximação entre as categorias de cultura, a partir da história cultural e memória visto que "a cultura, de certa maneira, cria um filtro através do qual as coisas são percebidas e, posteriormente, um novo filtro através do qual as coisas serão lembradas" (Carsalarde, 2014 p. 166). Para Carsalarde (2014), a cultura pode ser entendida como identidade coletiva e memória. A memória coletiva para Halbwachs (2013) é um ato de recordar que também só pode ser compreendido em um contexto social. A memória, longe de ser apenas uma recordação individual e subjetiva é compreendida como indissociável de um grupo social sobre o qual age e é atingida. Memória coletiva é um "fenômeno coletivo e social, ou seja, como um fenômeno construído coletivamente e submetido a flutuações, transformações, mudanças constantes" (Pollack, 1992 p.202). A memória coletiva é formulada por sujeitos. "Se podemos dizer que, em todos os níveis, a memória é um fenômeno construído social e individualmente, quando se trata da memória herdada, podemos também dizer que há uma ligação fenomenológica muito estreita entre a memória e o sentimento de identidade" (Pollack, 1992 p. 205).

Para falar de identidade, deve-se recordar que existe a identidade individual ou pessoal, que se relaciona na diferenciação entre si e os outros e a identidade social (ou coletiva) relacionada ao sentimento de semelhança entre alguns (outros). 0 processo indenitário é dinâmico e ocorre a partir da constatação de semelhanças e diferenças entre si, os outros e diferentes grupos (Deschamps \& Moliner, 2014). A identidade pode ser definida como "a localização em um certo mundo" formada por processos sociais (Berger \& Luckmann, 2008 p. 177). A identidade coletiva permite o sentimento de unidade, de continuidade e de coerência do sujeito em relação ao seu grupo. É essa identidade e sentimento de pertencimento que constitui o lugar produzido espacialmente, seja ele histórico ou de memória (Moreira, 2007). Segundo Halbwachs (2013) uma sociedade só se desenvolve em um enquadramento espacial, daí o que Abreu (2016 p.25) chamou de inseparabilidade do tempo e do espaço na memória, ocasionando um Lugar de memória.

O Lugar, conforme Ghione (2013 p.1) é algo espacialmente delimitado, fixo e baseado "em variáveis de permanência como a geografia, o clima e determinadas práticas e comportamentos sociais". Lugar também pode ser considerado como local de tempo e espaço específico, em que se percebe a Arquitetura e ainda, fenômeno de experiência humana (Carsalarde, 2014). Lugar de Memória seria, portanto, o espaço onde as lembranças são ancoradas. Lugares de memória possuem três dimensões: simbólica, funcional e material (Nora, 1993). Material da existência, funcional de relação com apropriações e sociabilidades praticadas e simbólica pela vontade de se arquivar ou perpetuar determinadas tradições ou acontecimentos. É a cidade (ou a arquitetura em sua materialidade) que ancora a memória no tempo (Abreu, 2016). 
O espaço, segundo Lefebvre (2006 p. 36) possui dimensão abstrata (espaço mental), física (material) e social (produto social). 0 carácter social do espaço encontra-se relacionado à forma de produção de determinada sociedade enquanto a prática social "engloba produção e reprodução, lugares especificados e conjuntos espaciais próprios a cada formação social, que assegura a continuidade numa relativa coesão". 0 espaço pode ser simultaneamente natural e social, prático e simbólico.

Considera-se a produção do espaço fruto da temporalidade e espacialidade de conformação socioespacial capitalista (Correa, 2016). Espaço também pode ser entendido como condição, meio e produto de reprodução da sociedade (Carlos, 2016). A compreensão do espaço passa pela compreensão da própria sociedade e portanto, de sua organização, ou cultura. Desse modo, a cultura, a memória coletiva e as identidades sociais são, portanto, agentes de produção do espaço.

Para Carlos (2016 p. 63), [...]

[...] a espacialidade das relações sociais pode ser efetivamente compreendida no plano da vida cotidiana, e, a partir desta, articulada e redefinida com plano da reprodução das relações sociais, vista a multiplicidade dos processos que envolvem a reprodução do espaço em seus mais variados aspectos e sentidos como pratica sócio espacial.

Espaços públicos urbanos podem ser enquadrados como lugares de manifestação da esfera pública e do exercício da cidadania. São ainda locais de prática e realização sociopolítica (Abrahão, 2008). A origem desses locais remota aos tempos clássicos da antiga Grécia e Roma, a partir da criação da vida em cidades e a instalação dos princípios da democracia, conforme pode ser visto nos estudos de Arendt (2007), onde tem-se a concepção de espaço público intrinsicamente relacionada a vida pública.

As relações entre publico e privado são explicitadas na distinção entre oikos ( comunidade privada ou domestica) e polis (comunidade pública), onde a polis envolve não apenas o espaço da cidade mas as relações sociais que ali se desenvolviam (Agambem, 2015). Desse modo, a dimensão do público refere-se à ação, atividade por excelência ligada ao politico. 0 político em Arendt significa "ação eminentemente intersubjetiva, mediante processos comunicacionais que irão se dar sob certas circunstancias que permitam a cada um expressar-se de forma livre, e sobre temas de ordem política" (Silva, 2017 p.121).

0 entendimento de esfera pública encontra-se então na dimensão da ação interagindo com o conceito de espaço público. Ação significa enunciar uma participação politica e estar na esfera pública, portanto, esfera pública não significa espaço público, mas pressupõe a existência de um, onde se localizam essas relações e sociabilidade. 0 espaço publico designa um conjunto de lugares resultado da interação humana onde são decididas e definidas as ações organizadas politicamente. Sendo o espaço publico fruto de trocas humanas, não haveria espaço publico natural e qualquer espaço da cidade é, portanto, social. Observa-se, portanto que o espaço público em sua dimensão material seria qualquer espaço em que não houvesse impedimento a participação das pessoas, independente da camada social, atuando em regime de civilidade.

Já o conceito de democracia para Silva (2017 p. 119) (baseado na interpretação de Hanna Arendt), pode ser visto como "presença ativa dos cidadãos nas praças e lugares públicos como lugar de debates deliberando sobre questões de ordem pública" enquanto a cidadania é considerada o exercício de direitos na vida política. Tanto cidadania quanto democracia possuem dimensões espaciais, tornando o espaço "condição e meio de exercício da cidadania” (Abrahão, 2008 p. 175).

Os espaços públicos emergem com grande valor social e espaços contínuos de sociabilidade cotidiana. "Ruas praças e monumentos transformavam-se em suportes físicos de significações e lembranças compartilhadas, tornando-se balizas reconhecidas de identidades, fronteiras de diferença cultural e marcos de pertencimento" (Abrahão, 2008 p. 172). Pode-se concluir então que qualquer espaço público tem potencial para ser político e fortalecer a troca e reconhecimento reciproco entre pessoas. 


\subsection{Paisagem cultural e patrimônio industrial}

Assim como o termo Cultura, Paisagem também possui múltiplos significados e interpretações. 'Desde espaço abarcado pela visão do observador' ou porção de terra específica à designação de forma, aparência. Entretanto, no campo sócio espacial, a definição de paisagem atinge o campo das relações sociais e interações que ocorrem entre o meio social e natural (Lopes, 2013 p. 46)

Como visto, as práticas sociais em diferentes temporalidades produzem espaço. Essas formas produzidas pelo homem em um contexto específico geram uma conformação compreendida como paisagem, que reúne elementos a natureza e da produção humana. Para Santos (2001 p. 67) "paisagem é o conjunto de formas que, num dado momento, exprimem as heranças que representam as sucessivas relações localizadas entre homem e natureza". Pode ser o conjunto dos elementos que distinguem um lugar ou ainda vários tempos presentes em sobreposição.

A arquitetura que compõe a paisagem integra a memória por sediarem os acontecimentos e assim essa memória coletiva se espelha na transformação do espaço realizado pela coletividade. Assim, para Santos (2001, p. 71) "A paisagem é apenas uma parte da situação. A situação como um todo é definida pela sociedade atual, enquanto sociedade e como espaço." Do conceito de paisagem surge a Paisagem cultural, que pode ser compreendida como diferentes interações entre a ação do homem e o espaço físico existente, natural ou produzido.

Desde 2009 a Paisagem Cultural passou a ser instrumento de preservação através do IPHAN. Essa chancela visa reconhecer as relações entre cultura humana e ambiente natural em territórios de conformações diferenciadas, autênticas ou singulares (Costa \& Gastal, 2010).

A Paisagem Cultural de determinado lugar ao ser reconhecido por meio do ato de tombamento, torna-se Patrimônio. A origem da palavra relaciona-se à esfera familiar, econômica e jurídica de uma sociedade. Derivado do latim - patrimonium - o termo referia-se a herança familiar, "algo que é transmitido, segundo as leis, dos pais e das mães aos filhos", ou, "a transferência de status baseada na relação existente entre dois membros de um grupo social, entre aquele que transmite e o que recebe" (Choay, 2001. p.11).

O patrimônio em sua composição apresenta tanto aspectos matérias (objetos) quanto imaterial (discurso), pois trabalha a ideia da herança de bens, posse e na tradição familiar, posição social e por isso tornou-se o símbolo entre o mundo das ideias e o mundo palpável. A união entre o legado material e imaterial, onde um não sobrevive sem o outro (Choay, 2001).

Para Carsalarde (2014 p.175), patrimônio engloba uma multiplicidade de sentidos como a "permanência do homem ou sobrevivência da cultura, identidade, diversidade [...]" entre outros. 0 que se torna patrimônio e o papel dos agentes técnicos que o chancelam abrange fatores sociais, culturais e políticos. "O que converte um objeto em patrimônio é seu significado" (Carsalarde, 2014 p.193). Para ele Patrimônio pode ser entendido como "sinal de nossa existência histórica" cercado de significados evocados pela memória.

As arquiteturas que conformam a paisagem podem ser entendidas como evidencias de costumes ou modos de vida, portanto, também são signos passíveis de decodificação através da cultura. 0 patrimônio industrial, de maneira mais específica, tem-se destacado como objeto de pesquisas mais recente. Traz a possibilidade de decodificação de signos que demonstram vestígios de sistemas de construção, equipamentos, armazenagem e modos de fazer econômico de determinada sociedade, torando-se um vasto campo pluridiscipinar de interpretação.

\section{Aspectos geográficos, culturais e históricos de formação da paisagem histórica urbana do município de Parnaíba}

A cidade de Parnaíba localiza-se na porção litorânea do estado do Piauí, Nordeste do Brasil (Figura 1). Possui dimensão territorial de 434,229km sendo a segunda maior do estado (atrás apenas da Capital, Teresina) e a mais relevante da microrregião do litoral Piauiense, Mesorregião Norte Piauiense. Encontra-se localizada nas coordenadas $02^{\circ} 5^{\prime}$ ' $17^{\prime \prime} \mathrm{S}$ de Latitude e $41^{\circ} 46^{\prime} 36^{\prime \prime} \mathrm{W}$ 
de Longitude em uma área de planície litorânea a $5 \mathrm{~m}$ de altitude do nível do mar.(IBGE, 2016). Faz divisa com as cidades de Buriti dos Lopes, Cocal, Bom Princípio, Luís Correia e Ilha Grande de Santa Isabel.

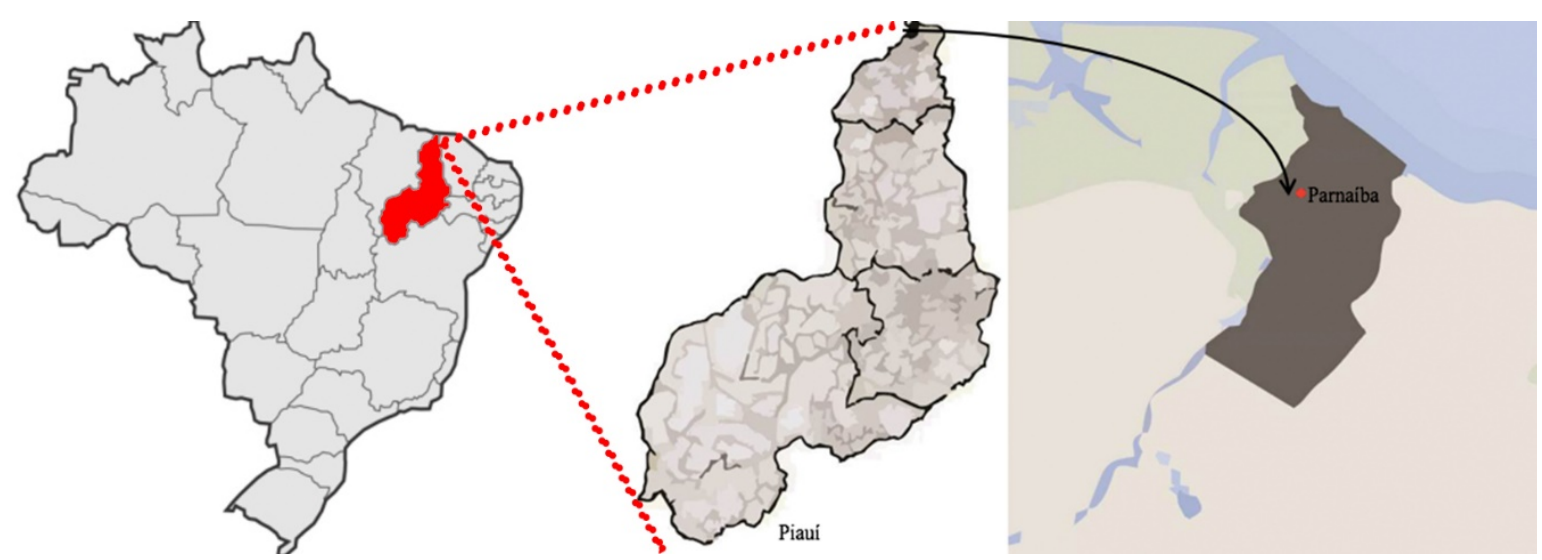

Figura 01. Imagem de satélite da cidade de Parnaíba [PI]. Fonte: GOOGLE EARTH, 2018 com modificações das autoras.

Com população estimada em 150 mil habitantes segundo dados do IBGE do ano de 2017, o clima é predominantemente quente e úmido com duas estações climáticas distintas: seca e chuvosa. A vegetação característica do local são a caatinga, o cerrado e a mata dos cocais. Situa-se na Bacia hidrográfica do Rio Parnaíba, divisa entre os estados do Piauí e Maranhão. Possui como atrativos turísticos naturais a faixa litorânea delimitada pela praia da Pedra do Sal e a proximidade geográfica com o município de Luís Correia e demais regiões litorâneas do estado do Piauí além de ser porta de entrada para o Delta do Parnaíba, único delta em mar aberto das Américas, onde se localizam os Lençóis Maranhenses. 0 delta forma-se a partir do encontro entre o Rio Parnaíba e o Oceano Atlântico, entre os estados do Maranhão e Piauí formando um estuário com área territorial de $2.750 \mathrm{Km}^{2} \mathrm{com} 65 \%$ da área pertencente ao Maranhão e 35\% no Piauí (Machado Jr. \& Macedo, 2016).

As principais vias de acesso rodoviário da cidade são: A BR 343, entrada da cidade a sul, que se transforma em av. Pinheiro Machado na zona urbana e cruza a cidade no sentido vertical, a Av. Princesa Isabel, via coletora que sai da BR 343 com destino ao centro na porção oeste do mapa, novamente, a BR 343, agora no sentido leste - oeste, ao norte do mapa, que direciona o local aos municípios litorâneos como a vizinha cidade de Luís Correia e a BR 402 que vem do estados vizinhos Ceará e Maranhão (Figura 2) Além dos acessos rodoviários a cidade conta com o Aeroporto internacional atualmente em funcionamento.

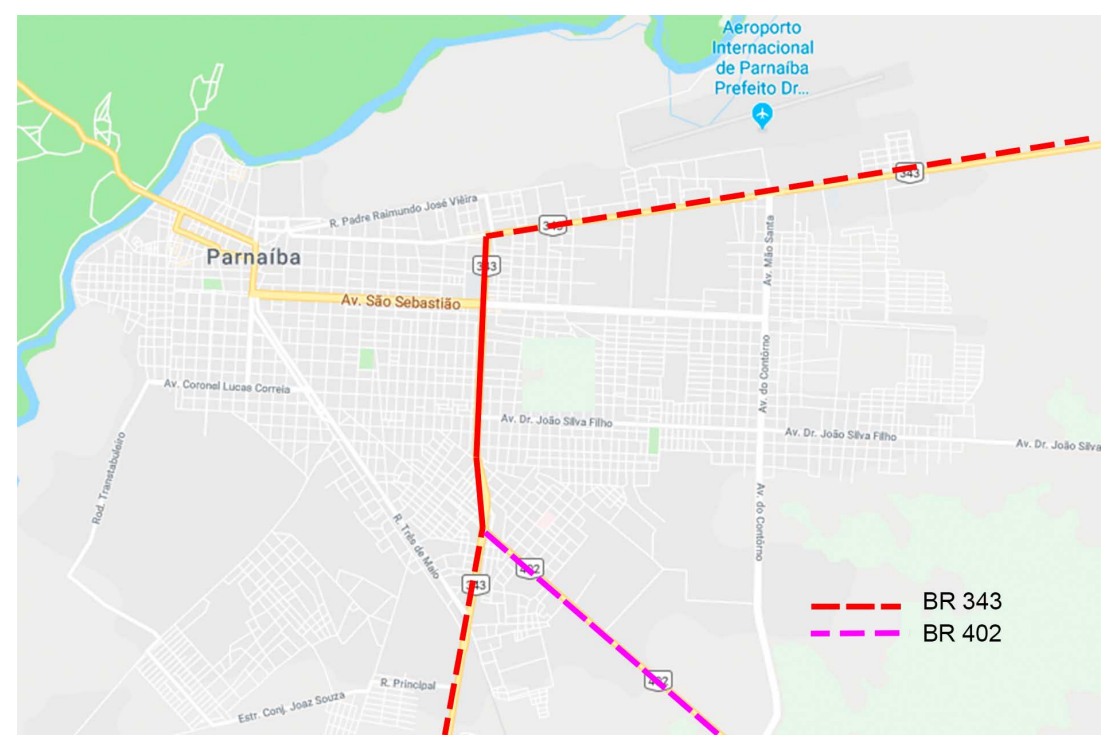

Figura 2. Mapas acessos rodoviários da cidade de Parnaíba Fonte: GOOGLE MAPS, 2018 com modificações da autora. 
As cidades piauienses desenvolveram-se a partir de fazendas de gado que, após instalarem-se originavam núcleos urbanos, tornando-se inicialmente freguesias, depois vilas e, posteriormente, cidades. Um dos primeiros povoamentos piauienses foi a Vila da Mocha (1717), no interior do estado, numa "tática de ocupação dispersiva" em função da atividade de produção pecuária (Silva Filho, 2007 p.12). Assim, "a povoação foi circunstancial, consolidando-se pelo comercio e amparada pela igreja [...] no semiárido piauiense foram as pastagens e o veio d’água que condicionaram as fixações do vaqueiro" (Silva Filho, 2007, p. 14).

Já nos anos de 1600 há indícios da presença europeia em litoral piauiense como afirma Silva Filho (2007 p. 9) ao se referir a formação dos agrupamentos urbanos no Piauí:

Os primeiros agrupamentos vão s instalar na segunda metade do século XVII, no período Pós Restauração. Céleres penetrações através do delta parnaibano, no último quartel do Seiscentos, assinalam a presença do Europeu naquele litoral. Longe ficaram de caracterizar uma ocupação territorial, quando muito incursões de reconhecimento.

Em muitas formações do Piauí havia viés apenas político administrativo no lugar de relevância estratégica ou econômica (Nunes, 1995), entretanto, no caso de Parnaíba, influenciada pela localização que possibilitava comunicação com o litoral, sua instalação possuiu condução diferenciada em relação as demais cidades piauienses. "Sua localização se deve ao comercio fluvial e marítimo, que a caracterizou como entreposto de transações da carne e couramas e não de criatório de gado bovino" (Silva Filho, 2007 p.87).

A proximidade com o Rio Igaraçu, garantiu, portanto, a localização da Vila de São João da Parnahiba (1762), que se tornaria a cidade em 1844. O assentamento original era no povoado Testa Branca, tendo sido transferido para a região do Porto das Barcas em virtude do progresso econômico. Dessa forma, a função de entreposto comercial se sobressaiu desde o início do assentamento.

Em 1762 foi erguido o Porto das Barcas. Em 1770, a sede da vila foi transferida para esse local devido ao progresso das trocas comerciais. Destaca-se na formação dos agrupamentos de origem portuguesa, de maneira geral, a função da igreja na estruturação do núcleo urbano, e, embora não tenham sido determinantes na escolha dos sítios de implantação, representavam os principais agentes modeladores das cidades coloniais (Vasconcelos, 2006).

No caso de Parnaíba "as igrejas se subordinam ao traçado regulador" visto que quando se estabeleceram já havia algum traçado ordenador (Silva Filho, 2007 p. 24). Acredita-se que a ordenação tenha sido implantando por volta de 1770 , identificando uma ordenação prévia e a consolidação das edificações mais relevantes de seu centro histórico. A posição de entreposto comercial consolidou-se ao longo do século XIX, fato este que influenciou diretamente nas conformações urbanísticas do local. Estima-se que as construções mais antigas sejam do sec. XVIII em especial na região do Porto das Barcas e Praça da Graça. Entre os materiais utilizados nos sistemas construtivos locais encontram-se cal de concha, uso de azulejos de manufatura portuguesa, misturada com carnaúba, situação diversa dos materiais encontrados nas nucleações do interior do estado.

Em 1914 esse traçado original se expande, com instalação de novas edificações. A avenida Getúlio Vargas estabelece-se como eixo comercial, dando lugar a construções de sobrados e implementação da arquitetura eclética, além de servir de comunicação com a Estação Ferroviária, se estendendo até o núcleo da Praça Santo Antônio. A Figura 3 apresenta o desenvolvimento urbano da cidade entre os séc. XVIII e XIX. A Figura 4, por sua vez, apresenta a evolução do tecido urbano da cidade até meados da década de 1970, onde observa-se um crescimento maior no eixo lesteoeste a partir da criação de novos bairros e conjuntos habitacionais.

Na primeira metade do séc. XX a economia de Parnaíba desenvolveu-se baseado na atividade agropecuária e extrativa, como já mencionado, além das atividades exportações. Por volta da década de 40 a cidade encontrava-se no ápice das transações de importações e exportações comerciais. De acordo com Silva (2012 p.113) foi "um fator preponderante para que aquela elite pudesse estreitar seus interesses e introduzir medidas de caráter modernizador no aspecto arquitetônico e urbanístico do município". 


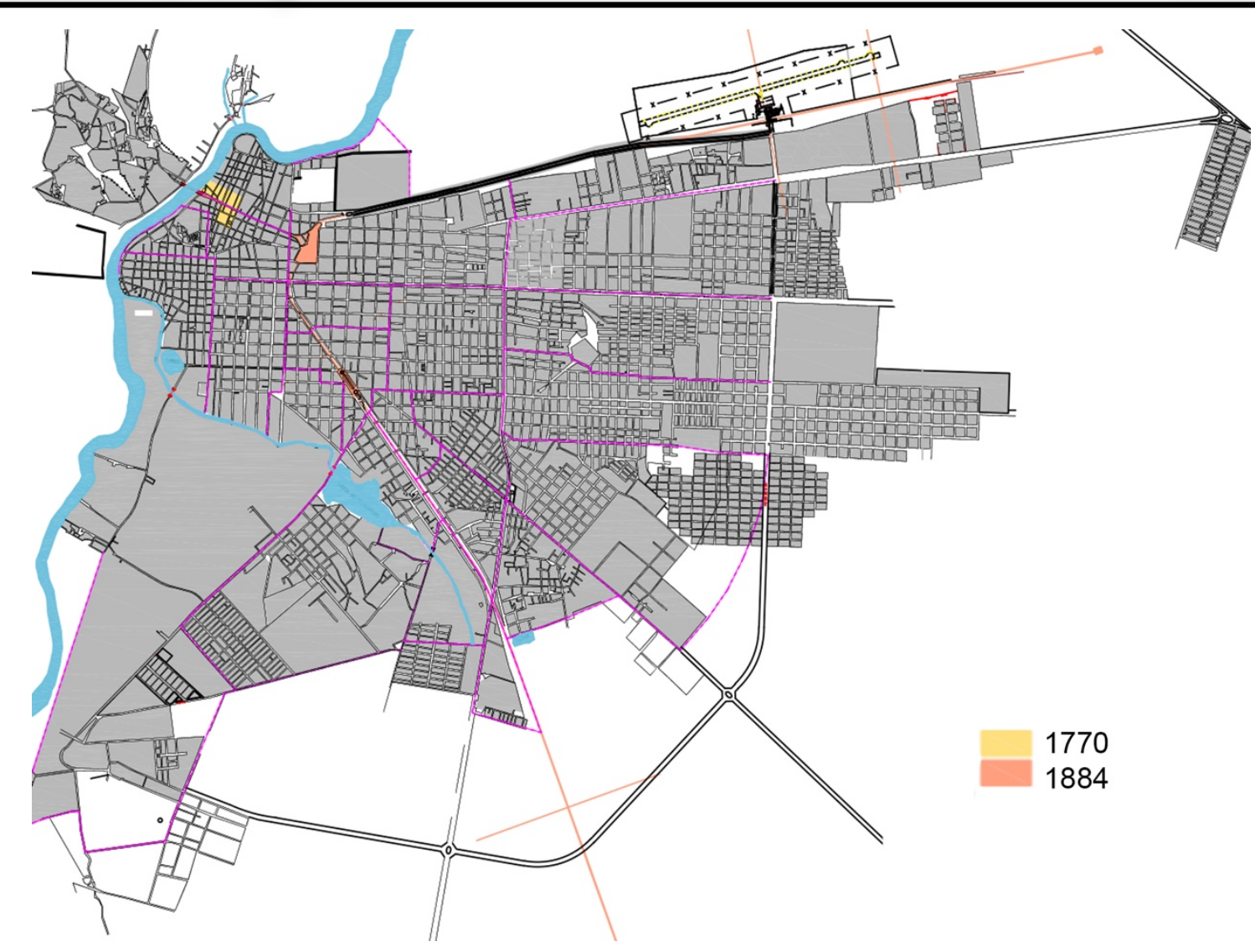

Figura 3. Parnaíba nos sec. XVIII e XIX. Fonte: PMP, 2016 com modificações das autoras.

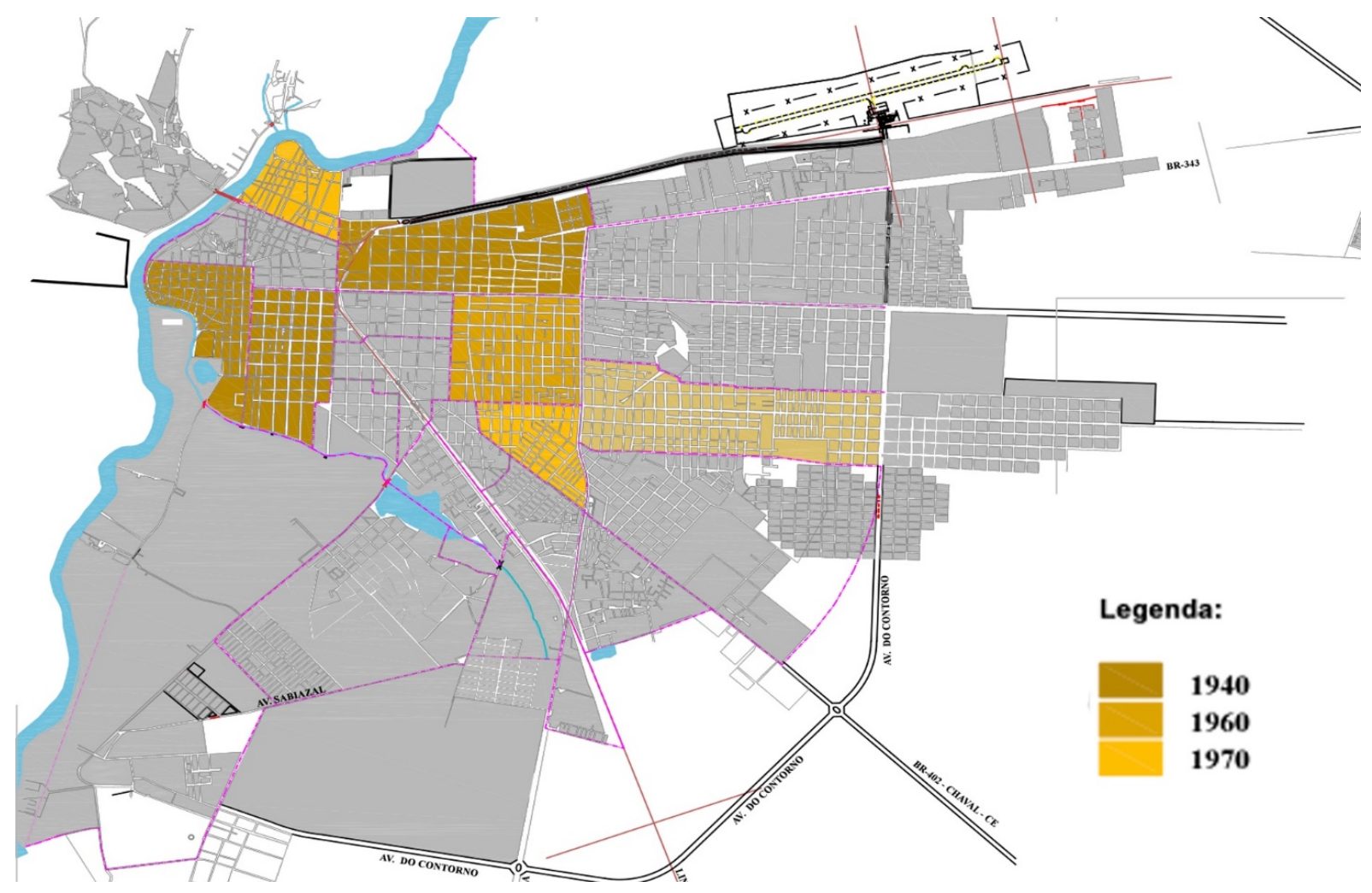

Figura 4. Parnaíba nos sec. XX. Fonte: PMP, 2016 com modificações das autoras. 
A arquitetura desenvolvida no período, de características ecléticas, se espalhou pela cidade em diversas formas construtivas e decorativas, sendo a origem principal a Inglaterra, justificada pela presença e influência de famílias e empresas inglesas em Parnaíba como era o caso da família Clarck e da empresa de importação Casa Marcs Jacob (Rodrigues, 2104).

Com a expansão do processo de rodoviarização brasileiro, acompanhado pelo declínio da navegação fluvial a cidade entrou em um processo de estagnação econômica que influenciou diretamente na preservação do sítio analisado. Atualmente a cidade apresenta vocação educacional, polo de assistência médica e turística para a microrregião, o que a leva a receber um elevado número de visitantes e novos moradores, modificando as relações de reconhecimento, identidade, pertencimento e preservação, criando novas formas de apropriar-se da cidade.

\section{Conjunto histórico e paisagístico Porto das Barcas e Galpões Portuários}

No ano de 2008 o IPHAN realizou o tombamento do Conjunto Histórico e Paisagístico de Parnaíba, por considerá-la importante área de preservação histórica e cultural. A área delimitada para o perímetro de proteção e o perímetro de entorno pode ser observada na Figura 5.

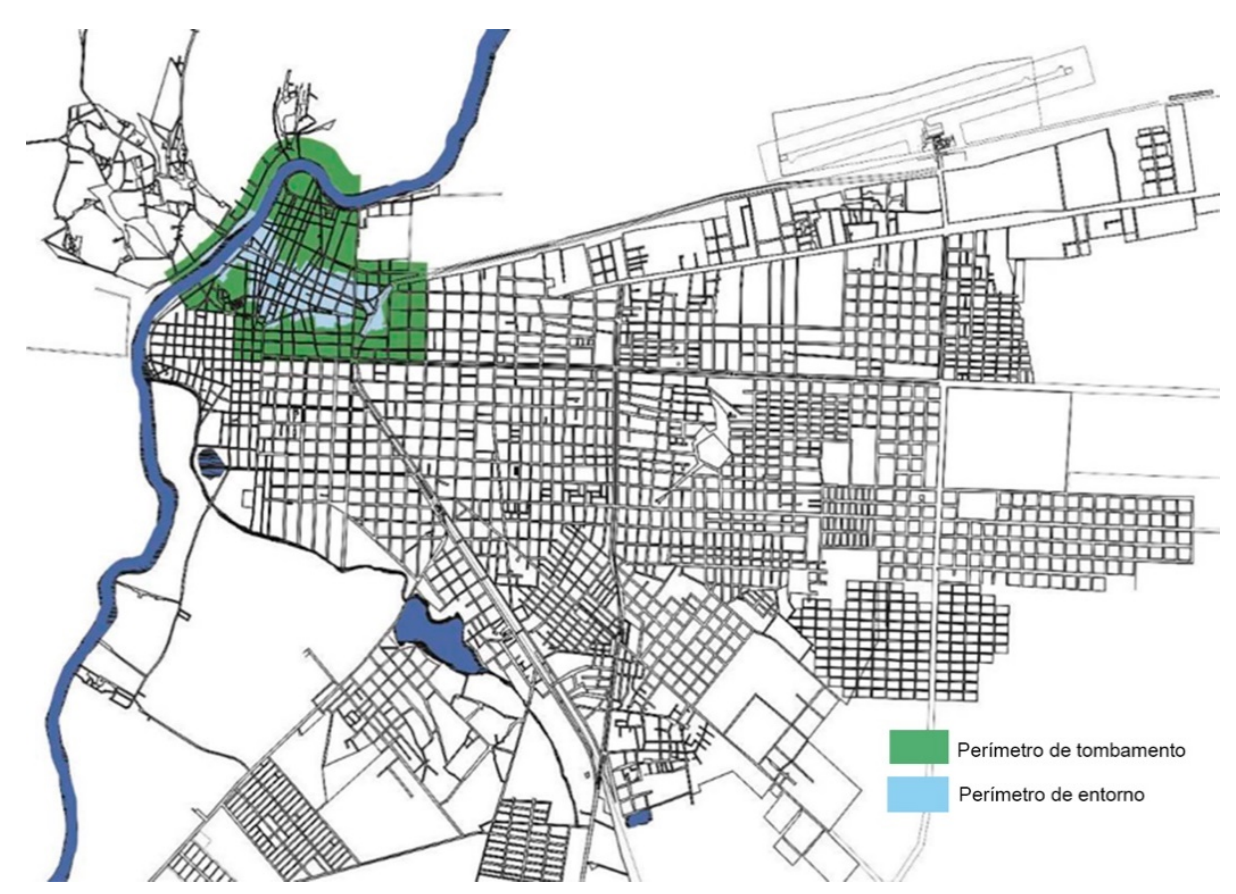

Figura 5. Perímetro de tombamento e entorno de Parnaíba. Fonte: IPHAN, 2008 apud Rodrigues, 2014

0 ato de tombar não se encontra vinculado ao atraso ou impedimento de uso. Visa antes proporcionar um correto desenvolvimento econômico e cultural para o local em que se insere pela valorização de edifícios antes abandonados ou em estado de ruínas (Kuhl, 2004).

O Tombamento não tem por objetivo "congelar" a cidade ou outro bem. Tombar não significa apenas cristalizar ou perpetuar edifícios ou áreas, sem considerar toda e qualquer obra que venha contribuir para a melhoria da vida na cidade (SEEC, 2010 p.1).

No Perímetro de Tombamento, as edificações e o traçado urbano encontram-se regulados pelo IPHAN no referente ao uso do solo, alterações de materiais de fachada e pavimentação e o que mais possa acarretar em transformação na paisagem, como publicidade e sinalização (IPHAN, 2008). A região de Entorno atua como área de passagem entre o preservado e o contemporâneo, também sujeitos às diretrizes que garantindo o equilíbrio no paradigma passado/ tempo presente (IPHAN, 2008). A divisão dos conjuntos que compõe o perímetro de tombamento pode ser observada na figura 06 . Nela distingue-se o sitio de cada grupo a ser preservado. 


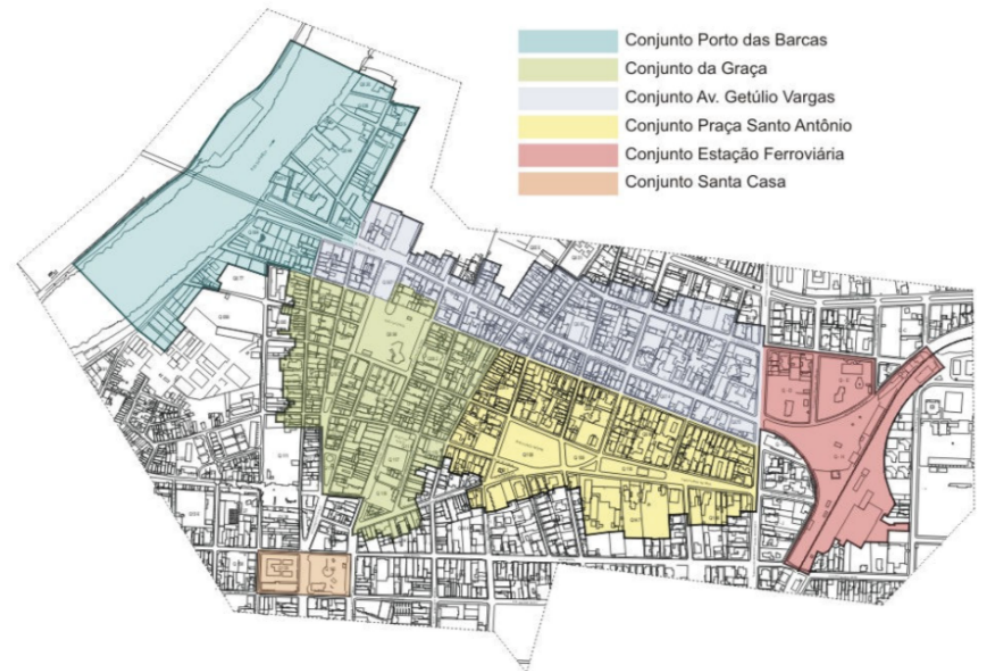

Figura 6. Divisão do Conjunto Histórico e Paisagístico de Parnaíba. Fonte: IPHAN, 2008.

São eles: Conjunto Porto das Barcas e Galpões Portuários, Conjunto Praça da Graça, Conjunto Av. Getúlio Vargas, Conjunto Praça Santo Antônio, Conjunto Estação Ferroviária e Conjunto Santa Casa de Misericórdia que serão brevemente comentados a seguir.

O mais antigo e objeto de análise do presente estudo é o Conjunto Porto das Barcas e Galpões Portuários (Figura 7), referentes ao cais do Rio Igaraçu, constituído de edificações essencialmente coloniais em suas formas e alinhamentos, sem recuos laterais, embora também ostentem alguns ornamentos típicos do período arquitetônico eclético, tipologia arquitetônica que se utiliza de diversos ornamentos e referências de diferentes temporalidades.

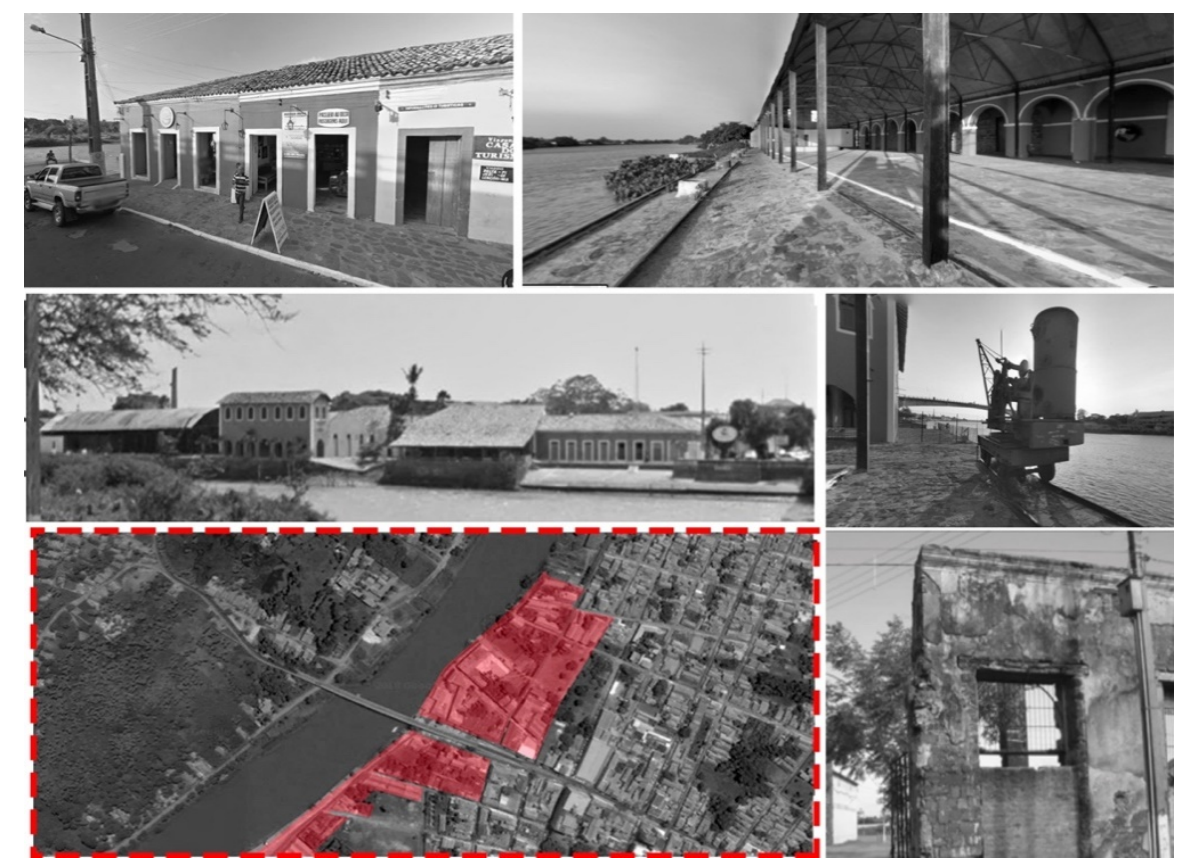

Figura 7. Conjunto Porto das Barcas e Galpões Portuários.

Fonte: IPHAN, 2008; Google Street View, 2018; Rodrigues, 2014, com modificações das autoras.

Essa conjunto arquitetônico e paisagístico distingue-se pela junção de dois grupos arquitetônicos que se situam as margens do Rio Igaraçu, o Porto das Barcas e Galpões Portuários. Os galpões portuários possuem data estimada de construção do final do séc. XIX e início do séc. XX enquanto as edificações do Porto são formadas por casarões germinados são remanescentes do séc. XVIII. A Figura 8 apresenta uma imagem histórica da região em meados de 1928. 


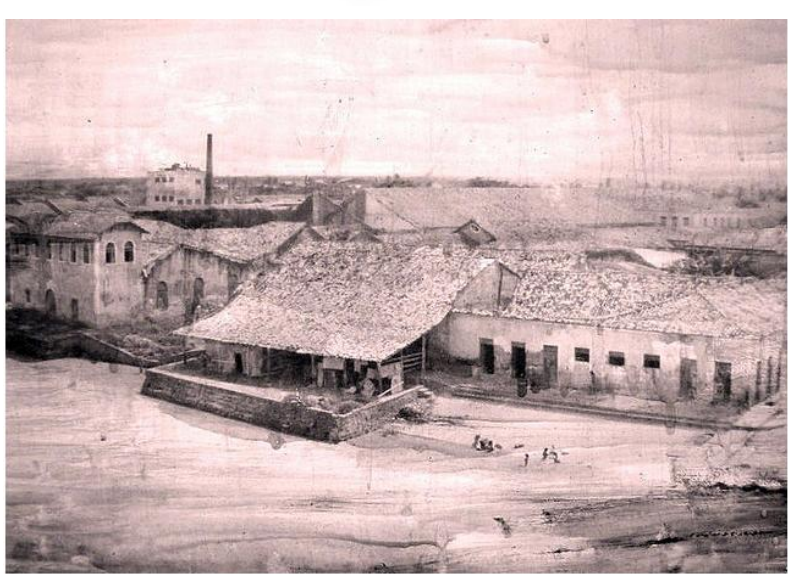

Figura 8. Região do porto das bancas no início do sec. XX. Fonte: Acervo IHGGP, 1928.
Essa região é uma das mais significativas historicamente, como já relatado, também paisagisticamente, por encontrar-se as margens do rio Igaraçu e por fim, culturalmente, tanto pelo estabelecimento da relação de Lugar de Memória, quanto pela apropriação da população no local.

Entre os galpões portuários remanescentes, destacam-se os de propriedade da companhia Franklin Veras e a Casa Inglesa. Também existem algumas industrias cujas edificações se destacam pelas chaminés como as pertencentes à indústria Moraes (Figura 9), atualmente desativada e em estado de ruínas (IPHAN, 2008).

Embora o atual estado de conservação de muitas das edificações esteja precário, parte o conjunto (Figura 10), onde encontra-se a Federação do Comércio e o conjunto do Porto abrigam comercio, restaurantes e lojas, tendo sido revitalizado nos anos 1990 (IPHAN, 2008). “Após obras de restauro realizadas na década de 1990, aquele que já foi chamado de porto salgado, refuncionalizado, se transformou em espaço cultural de entretenimento, com restaurantes, teatro ao ar livre, ateliês, minimuseu e pousada" (Ramos, 2008 p. 30).

A tipologia dos galpões é eclética ou Art Decó com telhados de elevada inclinação com estrutura em tronco de carnaúba. As fachadas sem ornamentação apresentam entre suas aberturas apenas portas, enfatizando a função comercial e de armazenamento (IPHAN, 2008). As paredes foram feitas de alvenaria de pedras com argamassa que incluía "cal, ostras e óleo de baleia" (Ramos, 2008 p.30). Muito do estado de conservação das edificações são ruínas, como podem ser observados na Figura 11. Nesses espaços, evidenciam-se as dimensões verticais pelo gabarito de único pavimento com pé direito mais alto devido à função que exerciam de armazenamento.

Na configuração original não existia a Ponte Simplício Dias (Figura 12), inaugurada em 10 de março 1975 na gestão do governador Alberto Tavares Silva.

Essa obra estruturante faz a transposição do rio ara os bairros de Santa Isabel e a Praia da Pedra do Sal, além do município de Ilha Grande do Piauí. Possui 300 metros de extensão e 9,2 metros de largura. Foi importante para o desenvolvimento do local e acesso, conforme já mencionado, para as áreas de interesse turístico e de conservação natural (IBGE, 2017). 0 sistema construtivo utilizado foi o de concretagem em balanços sucessivos (Dias, 2017). Na Figura 13 é possível ver o largo original que chegava até o Cais do então denominado Porto Salgado,

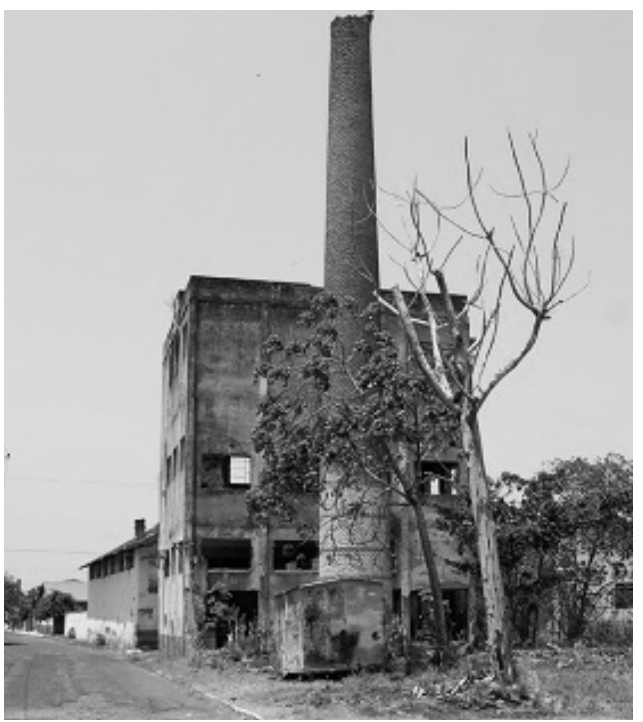

Figura 9. Indústria Moraes - ruínas. Fonte: PMP, 2014.

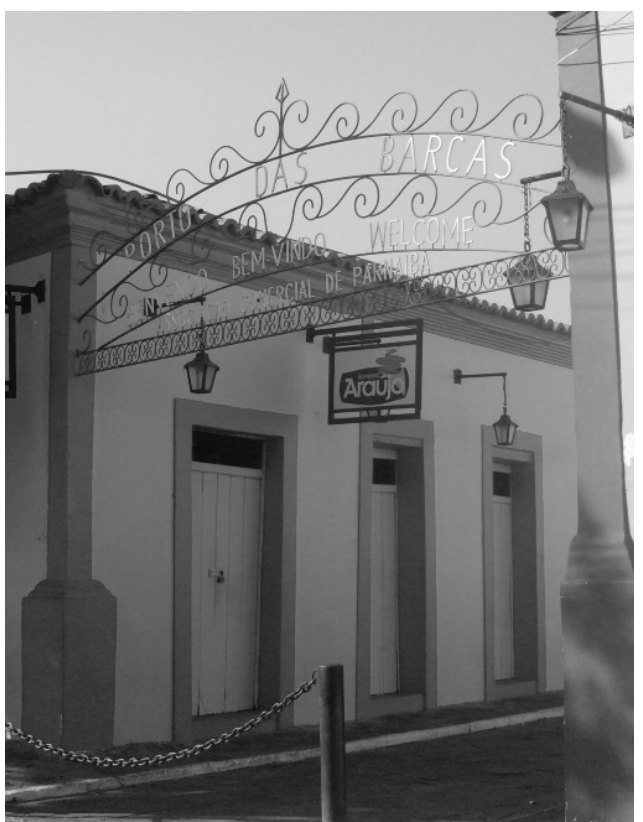

Figura 10. Entrada do Porto das Barcas. Fonte: Rodrigues, 2015 antes da inserção da ponte, que modificou a paisagem urbana do local. 


\section{Labor \& Engenho}

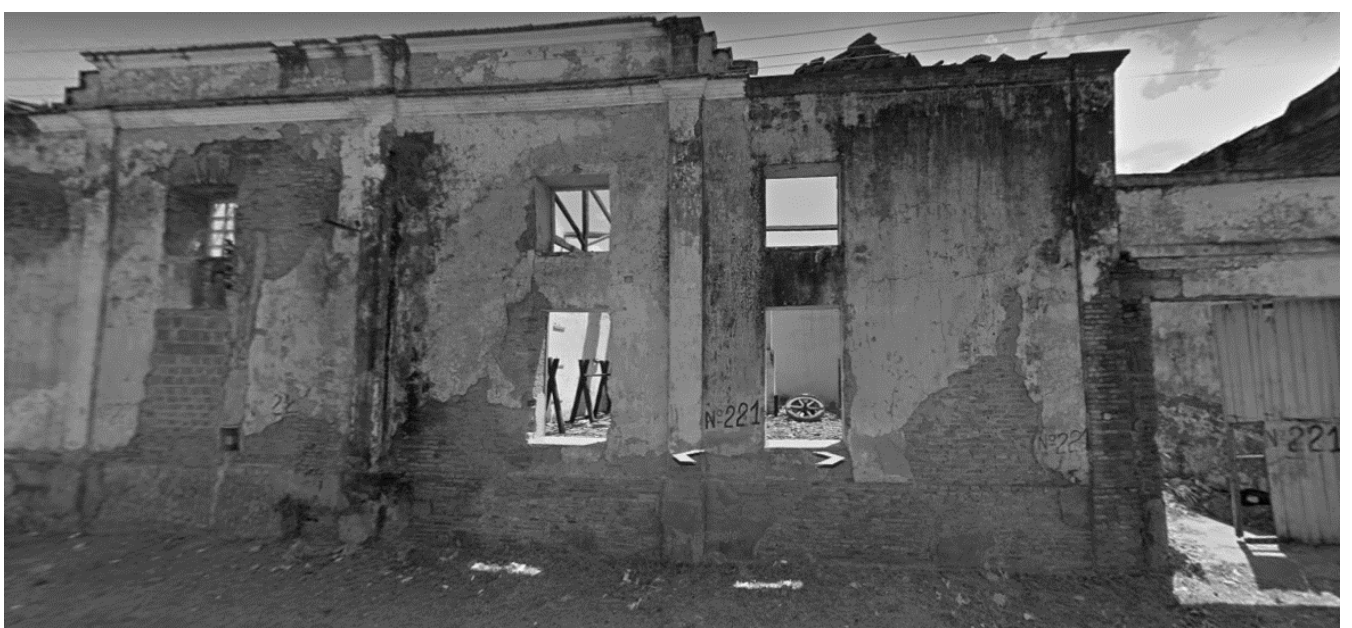

Figura 11. Conjunto Porto das Barcas e galpões portuários - ruínas. Fonte: Google Street View, 2018.

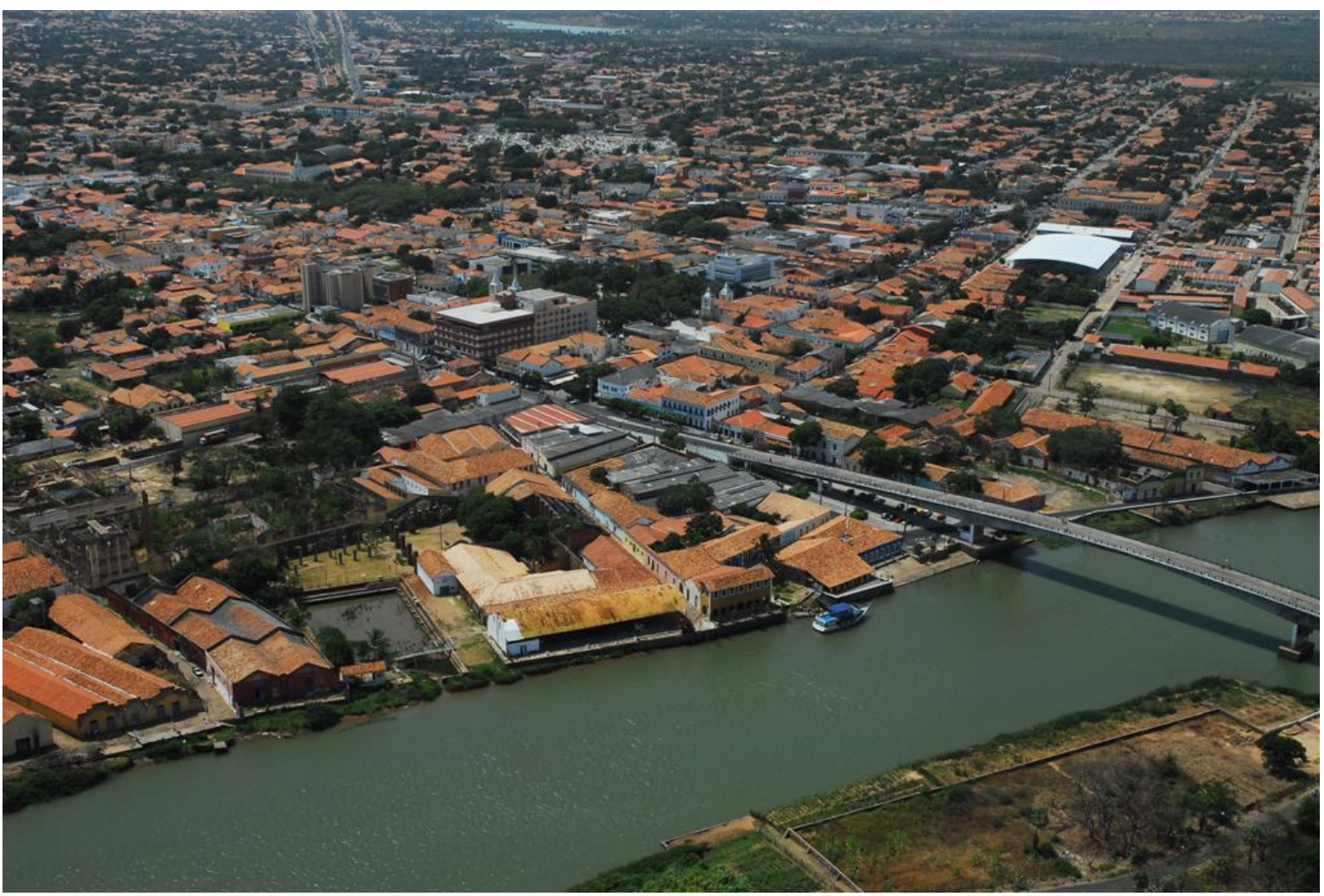

Figura 12. Vista Aérea da região do Porto das Barcas Fonte: IPHAN, 2008.
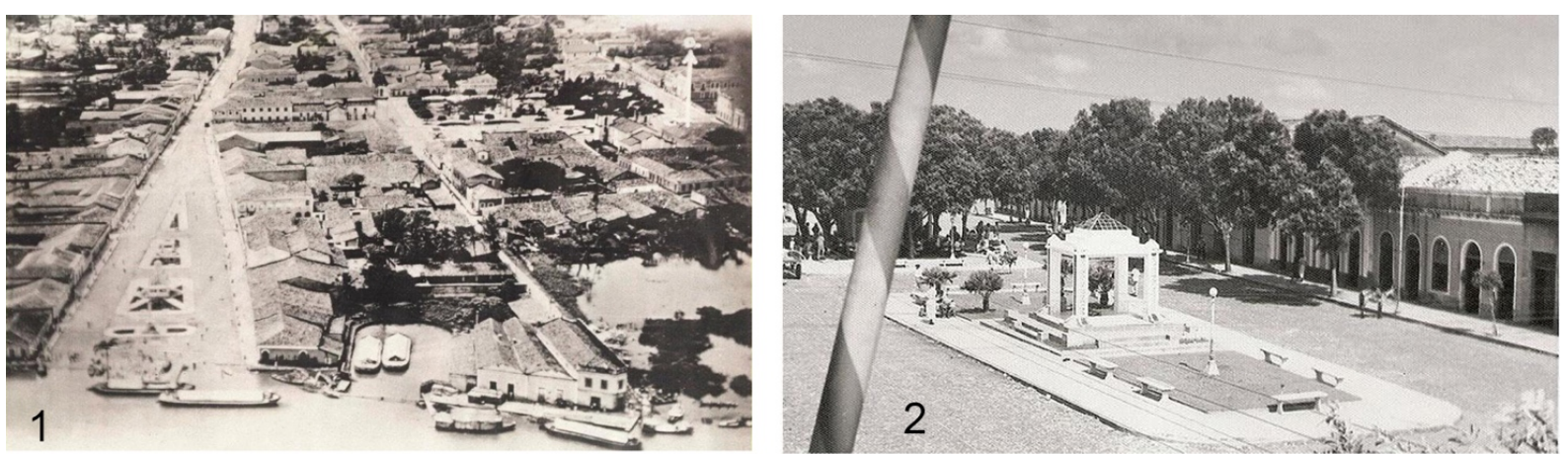

Figura 13. Largo no Porto Salgado antes da Ponte Simplício Dias.

Fonte: Acervo do IHGGP, [19- -]. 
Para construção da ponte foi deslocado um monumento existente, conhecido por Monumento da águia, implantado nos anos 30 na gestão do prefeito Ademar neves. Na Figura 14 é possível vê-lo, bem como o escoamento da produção do local (Souza, 2015).

Nas primeiras décadas do século XX, através de Parnaíba, o Piauí se integrou à dinâmica do capitalismo internacional, exportando algodão, borracha de maniçoba, cera de carnaúba e coco babaçu, além dos tradicionais produtos de sua pauta de exportação: couros e peles. Esses produtos, oriundos da agricultura e da atividade extrativa, eram requisitados no mercado internacional tanto para a indústria europeia quanto para a americana (IPHAN 2008, p.20).

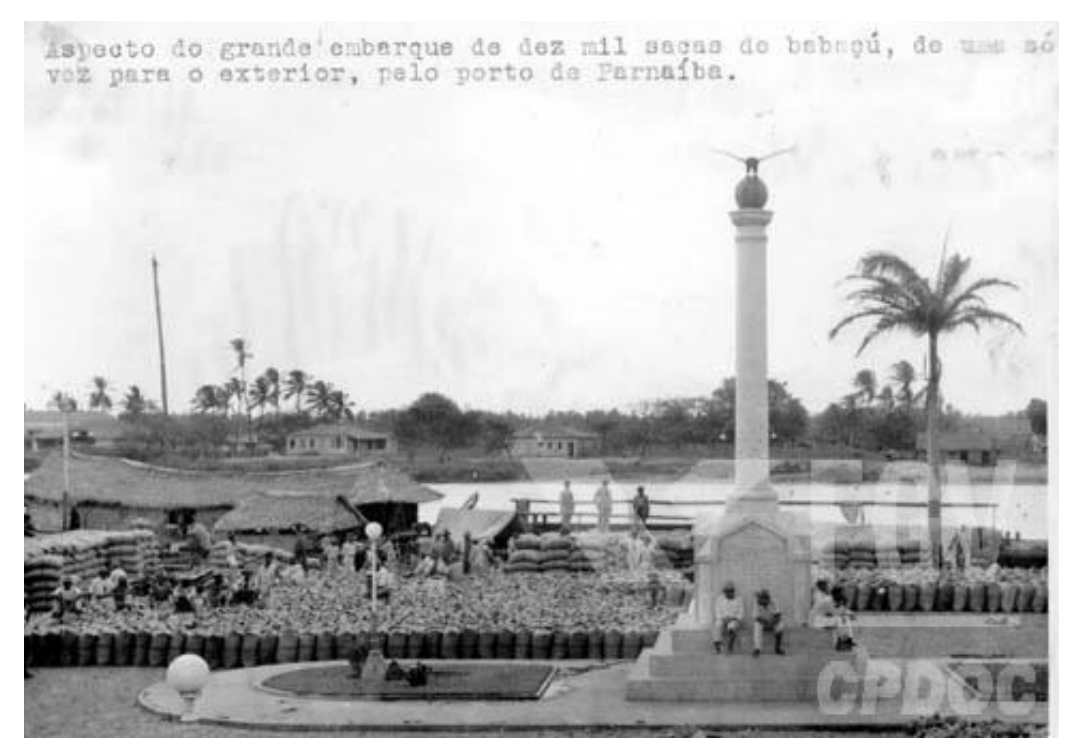

Figura 14. Monumento da águia em sua posição original. Fonte: CPDOC, [19- -].

Outras construções destacam-se pela expressão arquitetônica, como o caso do sobrado dos azulejos conhecido como Casarão dos Azulejos ou Solar da Poeta e a Casa Inglesa (Figura 15), de propriedade da família Clark que atuava no ramo da exportação, ambos de data estimada de construção de meados do sec. XIX (Napoleão Do Rego, 2010).
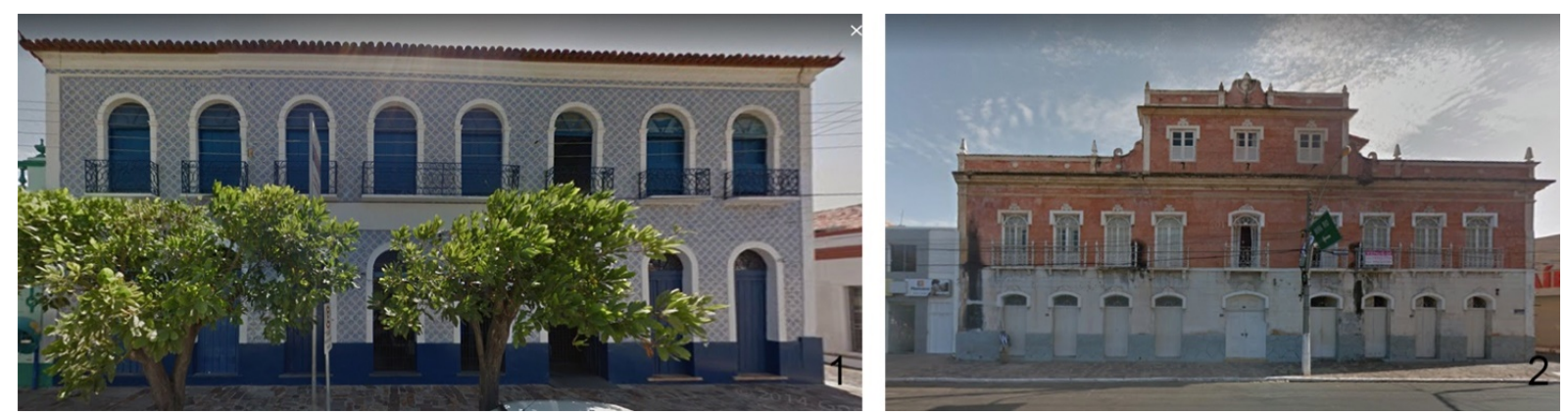

Figura 15. À esquerda, [1] Casarão dos Azulejos, à direita, [2] Casa Inglesa. Fonte: GOOGLE STREET VIEW, 2018 com modificações das autoras.

Conforme observado, as atividades comerciais que ajudaram no desenvolvimento e formação da paisagem urbana da cidade de Parnaíba e atuaram na região do objeto de estudo fazem com que o local tenha relevância desde ao origem da vida urbana no local, das atividades econômicas realizadas enquanto porto, pelas influencias culturais e construtivas oriundas da presença dos comerciantes estrangeiros e, mais recentemente, com as diferentes apropriações realizadas pela questão indenitária e de formação de lugar de memória.

As atividades comerciais exportadoras propiciaram a cidade de Parnaíba se tornar a capital econômica do Piauí. Essa posição só foi possível pela atuação dos comerciantes locais e das casas comerciais estrangeiras - a Casa Inglesa e a Casa Marc Jacob. Elas foram essenciais no processo de articulação da economia piauiense ao mercado nacional, nota- 
damente a economia do Ceará e do Maranhão, e ao mercado internacional. A atuação dos comerciantes estrangeiros a partir do século XVIII teve reflexos importantes não só sobre a economia, mas sobre a vida social e cultural da cidade de Parnaíba (IPHAN 2008, p.276).

Atualmente verifica-se a contínua apropriação social do local para fins de entretenimento, a partir da realização de apresentações musicais, festivais culturais, carnavais, e da presença de bares, restaurantes e agências de turismo, que atraem pessoas de diferentes faixas etárias e muitas vezes, ocupam a via pública e a área abaixo da ponte Simplício Dias. Na contemporaneidade o cais funciona para saída de pequenas embarcações para o passeio ao Delta do Parnaíba (Figura 16).

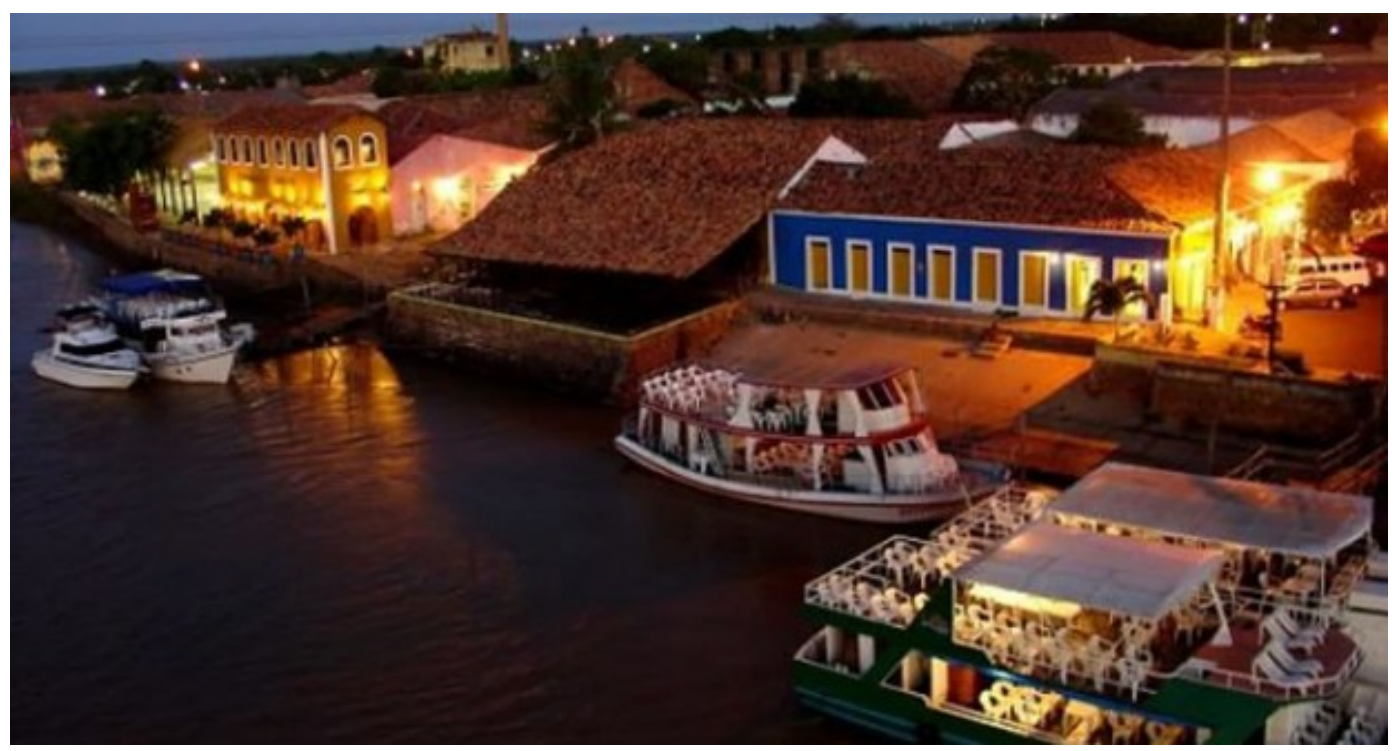

Figura 16. Porto das Barcas Fonte: SENA, 2017.

Durante muitos anos, ocorreram a realização de eventos e feiras comerciais visto que o local se encontrava cedido gratuitamente para a Associação comercial de Parnaíba. No ano de 2013, o município retomou o local com a previsão de inserção de uma reforma visando torna-lo Complexo Porto das Barcas, com locais de entretenimento e lazer (O Dia, 2013).

A partir da reflexão sobre as categorias de cultura, memória, identidade, espaço, democracia e paisagem, surgem alguns questionamentos pertinentes a essa pesquisa. Se o espaço é produzido por ação humana, o espaço público é o local onde as relações sociais acontecem no cotidiano e a democracia é o exercício de apropriação das pessoas, o que torna o patrimônio cultural democrático?

Retomando algumas discussões do referencial teórico, o patrimônio cultural democrático pode ser entendido como espaço produzido, de livre acesso e consequentemente apropriação aos sujeitos de qualquer camada social, livre de discriminação.

É evidente o potencial do objeto de estudo visto que não há barreiras, bilheterias ou qualquer outra restrição de usufruto do espaço, porém, sabe-se o quanto utópica essa ideia pode ser uma vez que para autores como Chaui (2008 p.58) "Isso é impossível, pois a sociedade de classes institui a divisão cultural" e, no caso específico do Porto das Barcas, o potencial reside na "cultura como ação histórica" (Chaui, 2008 p.68).

Essa distinção de uso por classes sociais fica em foco quando se verifica a apropriação da rua por mesas e cadeiras dos bares sediados no casario, ocasionando a privatização do espaço público visto que os logradouros e calçadas públicas passam a ser considerados extensões dos bares privados, produzindo um espaço de consumo para uma classe social específica.

Para Serpa (2007, p. 142) "a cultura é um motivo de conflito de interesses nas sociedades contemporâneas, um conflito pela sua definição, pelo seu controle e pelos benefícios que assegura", sobretudo aqueles membros da dita "cultura dominante" se fazendo necessário [...] 
[...] descontruir a hierarquia das diferenças, que transforma o que é diverso em desigual. [...] com a hierarquia não há possibilidade de construção de um diálogo profícuo entre os diferentes agentes e grupos que produzem cultura (Serpa, 2007 p. 143).

Dessa forma, o espaço como espetáculo e turismo cultural, acaba por ser fator de ruptura do espaço democrático no caso estudado, visto a necessidade de "capital escolar" para seu entendimento e construção das relações de identidade, estabelecendo um uso hierárquico do espaço, ainda que de maneira não explícita (Serpa, 2007).

\section{Considerações finais}

O patrimônio industrial do Conjunto Histórico e paisagístico de Parnaíba ainda é pouco conhecido e encontra-se em precário estado de conservação embora protegido pelos instrumentos legais de salvaguarda. O lugar de memória analisado possui íntima relação com o desenvolvimento econômico, social e cultural do sitio histórico da cidade, como pode ser observado no decorrer da pesquisa.

O tombamento do local em estudo e consequentemente a valorização da memória na contemporaneidade leva à retomada das raízes e das relações de identidade, um processo de valorização da memória urbana cada vez mais comum nas cidades brasileiras.

Independente de qual tenha sido o estoque de materialidades históricas que tenham conseguido salvar da destruição, as cidades do pais vem hoje engajando-se decisivamente num movimento de preservação do que sobrou de seu passado, numa indicação flagrante de que muita coisa mudou na forma como a sociedade brasileira se relaciona com as suas memorias (Abreu, 2016 p. 22).

A modificação a que se refere a autora é a postura de valorização do novo em detrimento do antigo, o que ocasionou a modificação de muitas das cidades em todo o país. "Desde o sec. XIX que se descobriu que a imagem urbana é uma mercadoria, que ela pode ser mercantilizada pode dar grande lucros, notadamente com o turismo" (Abreu, 2016 p. 23).

Observou-se no caso analisado que os espaços de valor patrimonial possuem potencial de apropriação democrática reforçado pelas relações de memória e identidade socialmente construídas pelos sujeitos em determinada espacialidade. Espaços ricos em história são mais propensos de apropriação espontânea pelas diferentes classes sociais. Entretanto, devem ser trabalhadas ações que incentivem a chamada "cidadania cultural" que "só é possível através de uma cultura da cidadania, viável apenas numa democracia" (Chaui, 2008 p. 75).

0 presente trabalho não conclui em encerra as investigações, antes, procura discutir as potencialidades e rupturas que são encontradas em espaços de preservação do patrimônio cultural urbano, sobretudo o industrial, a partir da análise específica do conjunto Porto das Barcas e Galpões Portuários, enfatizando o direito de todos de usufruto desses bens a todos e sobretudo “o direito à informação, sem a qual não há vida democrática" (Chaui, 1995 p. 82).

\section{Referências}

Abrahão, S. L. (2008). Espaço público, do urbano ao político. São Paulo: Annablume, Fapesp.

Abreu, M. (2016) Sobre a memória das cidades. In A. Carlos, M. Souza, \& M. Sposito. A produção do espaço urbano. Agentes e processos, escalas e desafios. São Paulo: Contexto.

Agambem, G. (2015). Stasis. Civil war as a political paradigma (N. Heron, tansl.). Edimburgo: Edimburgh University Press.

Arendt, H. (2007). A condição humana (Tradução de Roberto Raposo, posfácio de Celso Lafer) (10a. ed). Rio de Janeiro: Forense Universitária.

Bauman, Z. (2012). Ensaios sobre o conceito de cultura. Rio de Janeiro: Zahar. 
Benevolo, L. (1984). A cidade e o arquiteto. Editora Perspectiva: São Paulo.

Berger, P. L. \& Luckmann, T. (2008). A construção social da realidade: tratado de sociologia do conhecimento. Rio de Janeiro: Editora Vozes.

Carlos, A. F. A. (2016). Da "organização" à "produção" do espaço no movimento do pensamento geográfico. In A. Carlos, M. Souza, \& M. Sposito. A produção do espaço urbano. Agentes e processos, escalas e desafios. São Paulo: Contexto.

Carsalarde, F. (2014). A pedra e o tempo: a arquitetura como patrimônio cultural. Belo Horizonte: UFMG.

Chartier, R. (1990). A História Cultural: entre práticas e representações. Lisboa: Difel.

Chaui, M. (2008) Cultura e democracia. En: Crítica y emancipación: Revista latinoamericana de Ciencias Sociales, 1 (1). Buenos Aires : CLACSO.

Chaui, M. (1995) Cultura Política e política cultural. In Estudos avançados, 9 (23). São Paulo: USP.

Choay, F. (2001). A alegoria do patrimônio histórico; tradução de Luciano Vieira. São Paulo: Editora Estação da Liberdade.

Coelho Netto, J. T. (1993). A Construção do sentido na arquitetura. 3ed. São Paulo: Perspectiva.

Correa, R. L. (2016). Sobre agentes sociais, escala e produção do espaço: da "organização" à "produção" do espaço no movimento do pensamento geográfico. In A. Carlos, M. Souza, \& M. Sposito. A produção do espaço urbano. Agentes e processos, escalas e desafios. São Paulo: Contexto.

Costa, L. C. N. \& GASTAL, S. A. (2010) Paisagem Cultural: diálogos entre o Natural e o Cultural. In Anais do VI seminário de pesquisa em turismo do Mercosul. Caxias do Sul: Semitur.

Deschamps, J. C. \& Moliner, P. (2014). A identidade em psicologia social: dos processos identitários às representações sociais. Tradução de Lúcia M. Endlich Orth. Petrópolis: Vozes.

Dias. C. C. (2017). Engenharia Piauiense. Teresina: Sieart.

Geertz, C. (2014). A interpretação das culturas. Rio de Janeiro: Zahar.

Ghione, R. (2018). Tempo e Lugar. Recuperado de: <http://www.caupr.org.br/?p=6432>.

Halbwachs, M. (2013). A memória coletiva (Tradução de Beatriz Sidou) (2a ed). São Paulo: Centauro.

Heller, A. (1992). O cotidiano e a história (4a ed). São Paulo: Paz e Terra.

IBGE (2017) Porto das barcas. Recuperado de: <https://biblioteca.ibge.gov.br/biblioteca-catalogo.html? id=449149\&view=detalhes $>$.

IPHAN (2017). Anais do Colóquio Ibero-americano Paisagem Cultural, Patrimônio e Projeto. Belo Horizonte: IEDS 1(6).

IPHAN (2008). Conjunto histórico e paisagístico de Parnaíba. Teresina: 19 SR/PI.

Kühl, B. M. (2004). Arquitetura do ferro e arquitetura ferroviária em São Paulo. São Paulo: Ateliê Editorial/ FAPESP/ Secretaria de Cultura.

Lefebvre, H. (2000). A produção do espaço (Trad. Doralice Barros Pereira e Sérgio Martins do original: La production de l'espace. 4éd. Paris: Éditions Anthropos).

Machado Júnior, J. A. S. \& Macedo, J. P. (2016) A relação do turismo no Delta do Parnaíba com comunidades locais. In Cultur, 10 (1). Santa Catarina: UESC. 
Mendes, F. I. V. (2007) Parnaíba Educação e Sociedade (da Colonização ao fim do Estado Novo). Parnaíba: Sieart.

Moura, C. (2009) O advento dos conceitos de cultura e civilização: sua importância para a consolidação da autoimagem do sujeito moderno. In Filosofia. São Leopoldo: Unisinos.

Napoleão Do Rego, J. M. A. (2010) Dos sertões aos mares: história do comércio e dos comerciantes de Parnaíba (1700-1950). Doutorado em História Social. Universidade Federal Fluminense, Rio de Janeiro, RJ, Brasil.

Nora, P. (1993). Entre história e memória: a problemática dos lugares. In: Projeto História. São Paulo, 10, pp. 7-28.

Nunes, M. C. P. \& Abreu, I. G. de. (1995) Vilas e cidades do Piauí. In: R. N. Santana (Org.). Piauí, formação, desenvolvimento, perspectivas. Halley.

O Dia (2013). Porto das Barcas é doado à Associação Comercial de Parnaíba. Recuperado de: <https:// www.portalodia.com/noticias/piaui/porto-das-barcas-e-doado-a-associacao-comercial-deparnaiba-174170.html> .

Pinheiro, Á. \& Moura, C. (org.) (2010). Conjunto histórico e paisagístico de Parnaíba in Cadernos do Patrimônio cultural do Piauí, 2, Teresina: Superintendência do IPHAN.

Pollack, M. (1992). Memória e identidade social. Estudos históricos, 5 (10) pp.202-2015. Rio de Janeiro: CPDOC-FGV.

Prefeitura Municipal de Parnaíba (2016). Plano Diretor de Desenvolvimento sustentável. 3. Parnaíba: PMP.

Ramos, J. N. A. (2008). Parnaíba de A a Z: guia afetivo. Brasília: Multicultural Arte e comunicação.

Rapoport, A. (1984) Origens Culturais da Arquitetura. In J. C. Snyder \& A. Catanese. Introdução à Arquitetura. Rio de Janeiro: Ed. Campus Ltda.

Sacristán, J. G. \& Gómez, A. I. P. (1998). Compreender e transformar o ensino. 4.ed. Porto Alegre: ArtMed.

Santos, M. (2006). A Natureza do Espaço: Técnica e Tempo, Razão e Emoção (4a ed., 2a. reimpr.). São Paulo: Edusp (Coleção Milton Santos; 1).

SEEC. Secretaria de Estado da Cultura - Paraná. Tombamento - Conceitos. Recuperado de <http:// www.patrimoniocultural.pr.gov.br/modules/conteudo/conteudo.php?conteudo=4> .

Sena, J. (2017). Conheça o Porto das Barcas em Parnaíba. In Blog Mario Pires. Recuperado de: < http:// www.blogdomariopires.com.br/2017/12/conheca-o-porto-das-barcas-em-parnaiba.html> .

Serpa, A. (2007). O espaço público na cidade contemporânea. São Paulo: Contexto.

Silva F., O. P. da. (2007). Carnaúba, pedra e barro na Capitania de São José do Piauhy. Belo Horizonte: Rona. $3 \mathrm{v}$.

Silva, J. (2012). Parnaíba e o Avesso da Belle Epoque: cotidiano e pobreza (1930-1950). Mestrado em História do Brasil, Universidade Federal do Piauí. Teresina, PI, Brasil.

Silva, M. L. (2017). A ideia de espaço público em Hannah Arendt. In Cadernos Zigmut Bauman, 7 (13). São Luís: UFMA.

Sousa, D. (2015). Monumento da águia. In, Maloca Piauiense. Recuperado de: <http:// malocapiauiense.blogspot.com/2015/05/monumento-da-aguia.html> .

Vasconcelos, P. (s.d.). Os agentes modeladores das cidades brasileiras no período colonial. In I. Castro, P. Gomes, \& R. L. Correa. Explorações geográficas: percursos do fim do século. Rio de Janeiro: s.ed. 